\title{
IMPROVEMENT OF THE METROLOGICAL CHARACTERISTICS OF STATE PRIMARY STANDARD PHASE ANGLE BETWEEN TWO VOLTAGES UNIT BY MEASUREMENTS AUTOMATION
}

\author{
Kulish Yuliia, 4, Metrologichna, Str., Kyiv, 03143, Ukraine, +380445265568, \\ tifesmetric@gmail.com
}

\begin{abstract}
Materials on a research of short-term instability as incidentally making uncertainty of the State primary standard phase angle between two voltages are provided. The program project of automation of process of measurement by the measuring instrument phase angle is developed. Measurements of parameters of a short-term instability of the phase meter are completed. The equation of measurement and budget uncertainty in the calibration phase of the standard is reduced. It is shown that automation can improve the value of the uncertainty of the state standards, which are published in the form of CMCs on the site of the BIPM, and involve a reference to international comparisons.
\end{abstract}

\section{Introduction}

High accuracy and traceability of the phase measurements are required in the areas of measuring time and frequency synchronization, radar and navigation, aviation and aerospace, communications, energy, non-destructive testing, the playback size of the resistance units with alternating current, capacity and inductance, the development AC bridges and etc [1].In 2011 in SE "Ukrmetrteststandart" is created the State primary standard phase angle between two voltages unit for metrological maintenance phase measurements in the Ukraine. During the period of operation of the equipment set, which forms a group reproduction, preservation and transmission phase angle unit in the fundamental frequency range (from $5 \mathrm{~Hz}$ to $100 \mathrm{kHz}$ ) doubts about the reliability of estimation of the standard deviation as the reading is in the manual measurement mode of 20 values. In the analysis of the standard deviations for each year it was found unstable change values. In our opinion, it is connected with the low reliability of reading values and their numbers.

The aim of the article is: to show the improvement of the metrological characteristics of the State primary standard phase angle between two voltages unit by measurements automation.

\section{The main content of research}

The State primary standard consists of a set of measuring instruments of the fundamental range frequency (from $5 \mathrm{~Hz}$ to $100 \mathrm{kHz}$ ) and extended range frequency (from $0.01 \mathrm{~Hz}$ to 10 $\mathrm{MHz}$ ) [2] (Figure 1).

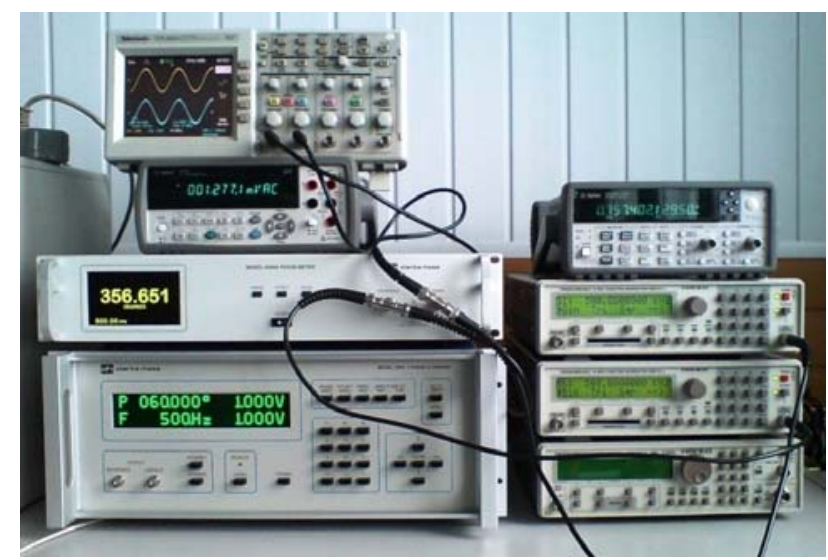

Figure 1. State primary standard phase angle between two voltages unit

Research of metrological characteristics of the State the primary standard phase angle between two voltages unit was executed for the random component of the uncertainty of measurements in the fundamental range frequency by direct measurements using a phase meter 6000A CLARKE-HESS and phase standard 5500-2 CLARKE-HESS. For the experiment, software was developed in the LabView environment for automatic reading of 
data to the computer from the 6000A CLARKE-HESS phase meter [3]. This decision to carry out the experiment allowed to increase the number of measured values to an unlimited value, which did not allow for manual mode in view of the difficulty of writing off the readings from the meter screen by the operator if the number of measured values is increased by more than 20.

Throughout the operation life of the instrument, the data obtained with internal calibrations have shown that the reliability of the mean square deviation is not enough, since the readings were read in the manual mode of measurement in the amount of 20 values at each point. The laboriousness of performing this operation in manual mode did not allow to increase the number of measurements sufficiently, which made automation possible.

The developed software has the form shown in Figures 2.

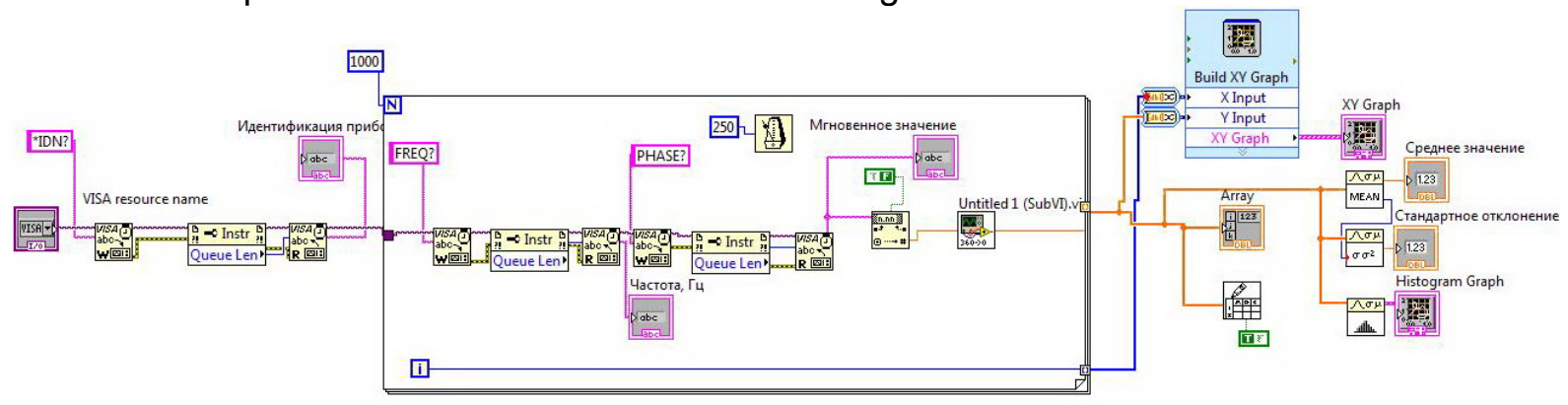

Figure 2. Block diagram of the automation program for the phase meter

Phase meter was calibrated with the phase standard the phase angle $0{ }^{\circ}$ reference signal, which is separated by a BNC within series adapters into two inputs of the phase meter (Figure 4) and other phase nonzero angle (Figure 5). The measurements were carried out for 20 minutes (the number of measurements of 5000 points) after 2 phase autozeroing operations (pressing the AUTOZERO key), which are separated by an interval of 30 seconds.

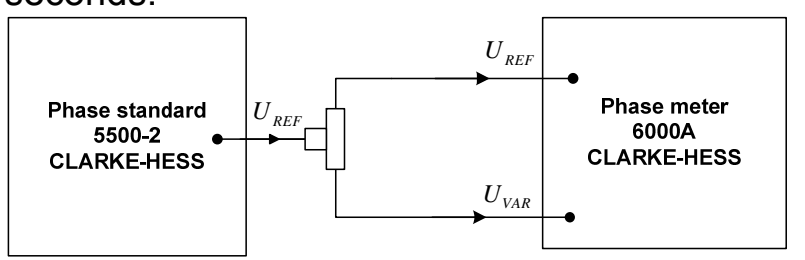

Figure 4. Diagram of measurement the phase angle $0^{\circ}$

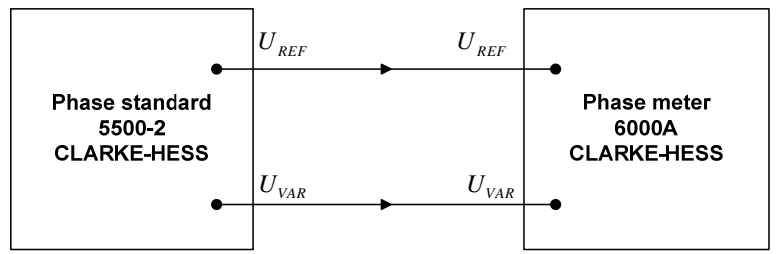

Figure 5. Diagram of measurement other phase nonzero angle

Phase standard CLARKE-HESS 5500-2 has been calibrated and received a certificate in PTB, Germany, for ensure traceability of the State primary standard in fundamental range frequency range, and was published CMC-lines in the database key comparisons (KCDM) BIPM (line number 36, SMS 38 tables) [4]. While CMC-lines was check it was recommended to recalculate the expanded uncertainty based on standard short-term instability, as this parameter is not taken into account when calibrating in the PTB, and that was taken from the operating instructions of manufacturer.

Since the real short-term instability of the meter is taken into account as a standard type A uncertainty and included in the expanded uncertainty, it makes it possible to assess the required short-term instability of the standard, and increasing the number of measurements reduces the standard type $A$ uncertainty and hence the standard and expanded uncertainty.

Measurements of the parameters of the short-term instability of the phase meter of the same signal of the phase standard at a value of the phase angle $0^{\circ}$ makes it possible to exclude the error of the meter and to estimate the short-term instability of the phase standard.

According to the standard procedure of calibration phase [5] measurement of the equation (1) (the deviation of the measured value of the nominal value) in absolute terms is as follows:

$$
\Delta \varphi_{X}=\varphi_{X}-\varphi_{S}+\Delta \varphi_{d X}+\Delta \varphi_{d S}+\Delta \varphi_{V}+\Delta \varphi_{f}+\Delta \varphi_{L}+\Delta \varphi_{T X}+\Delta \varphi_{T S}+\Delta \varphi_{\gamma}
$$


Where $\Delta \varphi_{X}$ - the deviation of the measured value of the nominal value;

$\varphi_{X}$ - reading phase angle offset calibrated phase meter;

$\varphi_{S}-$ the value of the phase angle, set by the standard phase (including the amendments specified in the calibration certificate for a given range point);

$\Delta \varphi_{d X}$ - correction due to the discrete scale of calibrated phase meter;

$\Delta \varphi_{d S}$ - correction due to the short-term instability phase standard;

$\Delta \varphi_{V}-$ correction due to the voltage deviation in the network;

$\Delta \varphi_{f}-$ correction due to frequency deviation of the test signal;

$\Delta \varphi_{L}$ - correction due to the difference of the lengths (and other characteristics) of the cable through which a signal;

$\Delta \varphi_{T X}$ - correction due to the temperature dependence of the calibrated phase meter;

$\Delta \varphi_{T S}-$ correction due to the temperature dependence of the phase;

$\Delta \varphi_{\gamma}$ - correction due to drift of the characteristics of the phase standard since the last calibration.

Table 1. Uncertainty budget in the calibration of the phase meter 6000A CLARKE-HESS.

\begin{tabular}{|c|c|c|c|c|c|c|}
\hline $\begin{array}{c}\text { Quantity } \\
X_{\mathrm{i}}\end{array}$ & $\begin{array}{c}\text { Estimate } \\
x_{i} \text { in } \\
\text { degrees }\end{array}$ & $\begin{array}{c}\text { Standard } \\
\text { uncertainty } \\
u\left(x_{\mathrm{i}}\right) \text {, in degrees }\end{array}$ & $\begin{array}{l}\text { Probability } \\
\text { distribution }\end{array}$ & $\begin{array}{c}\text { Method of } \\
\text { evaluation } \\
(A, B)\end{array}$ & $\begin{array}{c}\text { Sensitivity } \\
\text { coefficient } \\
c_{\mathrm{i}}\end{array}$ & $\begin{array}{c}\text { Uncertainty } \\
\text { contribution } \\
c_{\mathrm{i}} \cdot u\left(x_{\mathrm{i}}\right) \text {, in degrees }\end{array}$ \\
\hline$\varphi_{X}$ & 0,0002 & 1,17E-04 & normal & $A$ & 1 & 1,17E-04 \\
\hline$\varphi_{S}$ & $-0,0008$ & 2,50E-03 & normal & $B$ & 1 & $2,50 \mathrm{E}-03$ \\
\hline$\Delta \varphi_{d X}$ & 0 & $5,00 \mathrm{E}-04$ & rectang. & $\mathrm{B}$ & 1 & $5,00 \mathrm{E}-04$ \\
\hline$\Delta \varphi_{d S}$ & 0 & 2,89E-03 & rectang. & B & 1 & 2,89E-03 \\
\hline$\Delta \varphi_{V}$ & 0 & 8,50E-06 & normal & $\mathrm{B}$ & 1 & 8,50E-06 \\
\hline$\Delta \varphi_{f}$ & 0 & $5,00 \mathrm{E}-04$ & rectang. & B & 1 & $5,00 \mathrm{E}-04$ \\
\hline$\Delta \varphi_{L}$ & 0 & $5,00 \mathrm{E}-04$ & rectang. & $\mathrm{B}$ & 1 & $5,00 \mathrm{E}-04$ \\
\hline$\Delta \varphi_{T X}$ & 0 & 1,50E-06 & rectang. & $B$ & 1 & $1,50 \mathrm{E}-06$ \\
\hline$\Delta \varphi_{T S}$ & 0 & 1,50E-06 & rectang. & $\mathrm{B}$ & 1 & $1,50 \mathrm{E}-06$ \\
\hline$\Delta \varphi_{\gamma}$ & 0 & 7,16E-04 & rectang. & B & 1 & $7,16 \mathrm{E}-04$ \\
\hline$\Delta \varphi_{X}$ & 0,0010 & & & & & \\
\hline & & \multicolumn{3}{|c|}{ Combined standard uncertainty } & & 3,98E-03 \\
\hline & & \multicolumn{3}{|c|}{ Effective degrees of freedom } & $n_{\text {eff }}$ & $>200, k=2$ \\
\hline & & \multicolumn{3}{|c|}{ Expanded uncertainty $(p=95 \%)$} & & 7,97E-03 \\
\hline
\end{tabular}

In the uncertainty budget (Table 1), when calibrating the phase meter, there is, which a value of the standard uncertainty of type $A$ (value $1,17 \mathrm{E}-04^{\circ}$ ) is the real short-term instability of the meter.

Uncertainty in type $A$ is determined by the expression $[6,7]$ :

$$
u_{A}=\sqrt{\frac{1}{n(n-1)} \sum_{i=1}^{n}\left(\varphi_{X i}-\bar{\varphi}_{X}\right)^{2}} \text {, }
$$


where $\bar{\varphi}_{X}=\frac{1}{n} \sum_{i=1}^{n}\left(\varphi_{X i}\right)$ - arithmetic mean of measurement results, $\varphi_{X i}$ - The value of the phase angle, measured with a phase meter, $n$ - Number of measurements.

Figure 6 is showed the dependence of the standard uncertainty of type A on the number of measurements from 20 values to 5000 . Measurements at a frequency of $100 \mathrm{~Hz}$ are plotted as a dotted line at a frequency of $1 \mathrm{kHz}$ - solid. More measurements (reduces the standard type A uncertainty at all frequencies, as a short-term instability of the phase meter, and improves the extended uncertainty of the meter.

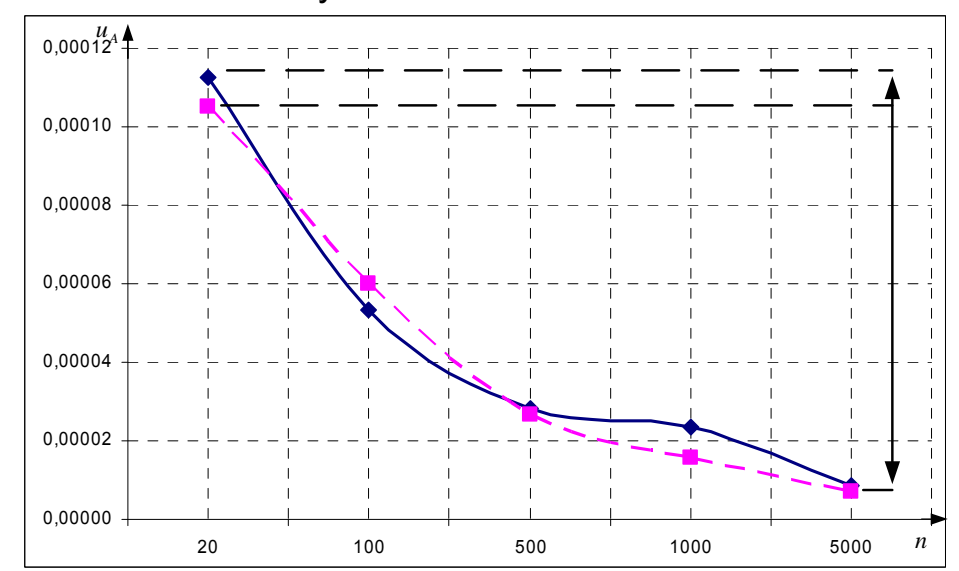

Figure 6. Graph of the dependence of the standard uncertainty of type A on the number of measurements

Research of short-term instability by automation the resulting value of standard uncertainty of type $A$ was the value $5,84 \mathrm{E}-06^{\circ}$ which is 14 times less than in the manual mode of phase measurement, and the expanded uncertainty decreased by 2 times.

\section{Conclusions}

The software automate the process of measuring the phase meter, which is part of the State primary standard of the phase angle between two voltages is developed. Automation improves the metrological characteristics of the State primary standard by assessing and reducing the random component of uncertainty. These metrological characteristics can improve the value by 2 times of the standard uncertainties which are published in the form of CMCs on the site of the BIPM, and involve a reference to international comparisons. Proposed software automation phase angle measurement process can significantly reduce the cost of providing metrological services by increasing productivity and reducing laborintensive.

\section{Reference}

1. Ю.В. Куц, Л.М. Щербак. Статистична фразометрія - Тернопіль: Тернопільський держ. техн. ун-т., 2009. - 384 с.

2. Державний первинний еталон одиниці кута зсуву фаз між двома напругами ДЕТУ 09-07-11. Паспорт. Держспоживстандарт, м. Київ, 2011. - 3 арк.

3. Кудрин А.В. Использование программной среды LABVIEW для автоматизации проведения фризических экспериментов. Электронное учебно-методическое пособие. Нижний Новгород: Нижегородский госуниверситет, 2014. - 68 с.

4. О.М. Величко, С.М. Шевкун, М.В. Добролюбова, Ю.М. Ізбаш Оцінка невизначеності при калібруванні фразометрів на державному еталоні кута зсуву фаз між двома напругами в основному діапазоні частот // Системи обробки інформації. - 2015. № 2 (127). - C. $86-88$.

5. МКУ 117-11/09-2015 Інструкція. Метрологія. Фазометри. Методика калібрування.

6. ЕА-4/02 М:2013 Вираз невизначеності вимірювання при калібруванні.

7. ДСТУ Н РМГ 43-2001 Рекомендации по межгосударственной стандартизации. ГСИ. Применение «Руководства по выражению неопределенности измерений» (Рекомендації з міждержавної стандартизації. 